\title{
The UCLA Sephardic Archive Initiative: Finding the Keys to an Untold History
}

\author{
Max Modiano Daniel \\ University of California, Los Angeles
}

\begin{abstract}
This essay introduces the scope and aim of the Sephardic Archive Initiative at the University of California, Los Angeles. In conjunction with the Library, Special Collections, and the Alan D. Leve Center for Jewish Studies, this project seeks to locate, collect, archive, and share documents and ephemera relating to Sephardic history. With a focus on their journeys to Los Angeles and Southern California, the initiative aims to tell the stories of Jews from North Africa, the Middle East, the Mediterranean, the Balkans, and the lands of the former Ottoman Empire. The transnational ties of Sephardic commercial, intellectual, religious, social, and family networks have produced a richly tangled web of history, which for the past century has found a thriving base in Los Angeles. The project seeks to create a hub of scholarly and communal investment, interest, and exploration of materials related to the Sephardic past.
\end{abstract}

Keywords: Sephardic; Mizrahi; Sephardic studies; Jewish Los Angeles; community collections; archives; UCLA; California

\section{INTRODUCTION}

The academic study of modern Sephardic life has entered a new phase over the past twenty years, having been largely ignored within the broader field of Jewish studies. Until then, most published works on American Sephardim (such as Angel 1982; Papo 1987; Sutton 1979) were written by community leaders and lay scholars, who relied on a combination of autobiography, self-curated archives, and narrowly defined institutional or organizational records for their research. A recent exception is the early work of Professor Aviva Ben-Ur, which draws on a more diverse array of sources and has been published in academic presses.

Libraries and archives in the United States that are dedicated to preserving and providing access to materials from and about the Jewish past generally emphasize the history of the Ashkenazi Jews of Central and Eastern Europe. Although scholars have advocated preserving documents and artifacts of Sephardic Jews (Baron 1950; Ben-Ur 2001), there are very few collections of American Sephardic history and culture. Noteworthy attempts to establish archives were intermit- 
tently undertaken by the American Sephardic Federation (ASF) and the Washington State Jewish Historical Society. The ASF archives are now held at the Center for Jewish History in New York, following the merger of the ASF and the Center in 2000. The Washington State Jewish Historical Society archives were especially active in the 1980s, gathering dozens of oral histories, but its collection efforts have largely subsided and its archives are now housed in Special Collections at the University of Washington Libraries in Seattle, where a considerable effort to collect records of American Sephardic Jews is being made by Professor Devin Naar and his team. A similar undertaking to collect, preserve, and showcase Sephardic history is currently underway at the University of California, Los Angeles (UCLA). It is no accident that recent projects to collect Sephardic source materials were established at UCLA and at the University of Washington, two of the handful of universities in the world with endowed chairs in Sephardic studies.

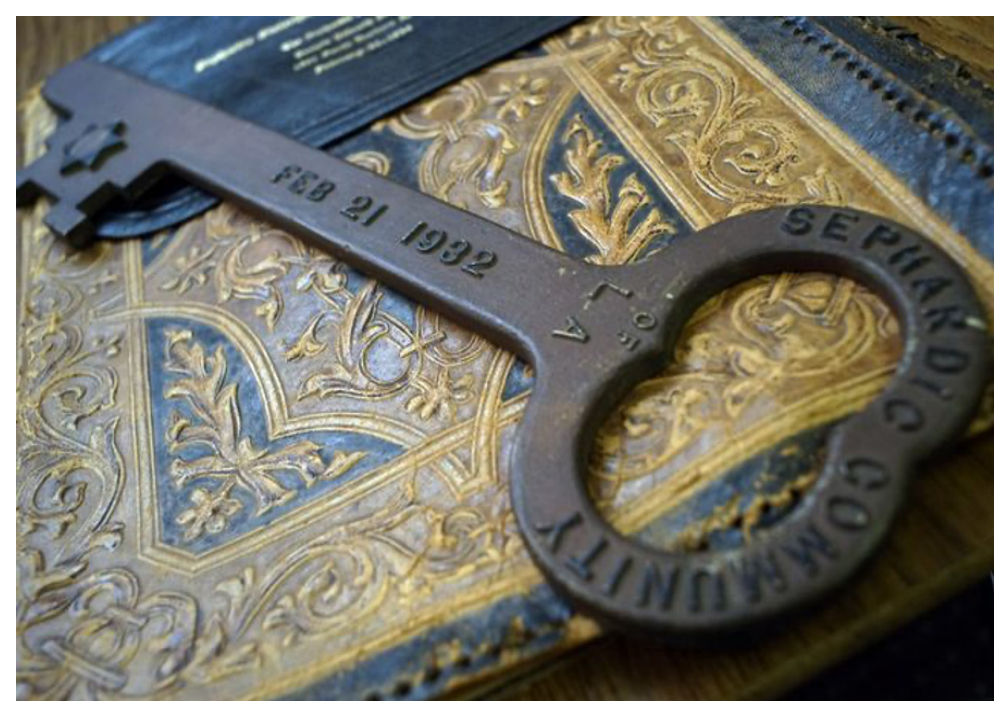

Figure 1. Oversized commemorative key for groundbreaking of a new temple building, 1932. Sephardic Temple Tifereth Israel records (Collection 2340), UCLA Library Special Collections

Launched in early 2015 under the directorship of Professor Sarah Abrevaya Stein-who holds the Maurice Amado Chair in Sephardic Studies and is the Sady and Ludwig Kahn Director of UCLA's Alan D. Leve Center for Jewish Studies - the UCLA Sephardic Archive Initiative (SAI) has been gathering source materials related to Sephardic history in partnership with the UCLA Library. The impetus for the Sephardic Archive Initiative (SAI) was concern about the relative obscurity of Sephardim on both the academic and public stages. Seeking to centralize, publicize, and professionalize the study of Sephardim, the SAI supports the growing field of Sephardi/ Mizrahi studies, especially in the United States

SAI is a home to a number of important acquisitions. The Moreno and Dagmar Gabay Book Collection contains over 150 volumes of Sephardic religious and devotional works written in Hebrew and Ladino (Judeo-Spanish), printed between the seventeenth and twentieth centuries in the Ottoman and Italian Jewish publishing centers. Al and Rose Finci family papers provide an 
intimate portrait of a couple whose paths crisscrossed Hitler's Europe - in Yugoslavia, Poland, and Italy - and who established themselves in Los Angeles after the Holocaust. The Danielle Avidan and Anna Mereille Abitbol Papers, SAI's most recent acquisition, highlight the lives and careers of a mother and daughter who navigated the world of art and high culture in mid-twentieth century Morocco and France. These collections are at various stages of processing at the UCLA Library's Special Collections. The first major acquisition of the initiative was the archival holdings of the Sephardic Temple Tifereth Israel (STTI), a community whose roots reach back to the second decade of the twentieth century and the beginnings of Sephardic settlement in Los Angeles. Being SAI's most substantial acquisition, this paper focuses primarily on the STTI.

\section{The Sephardic Temple Tifereth Israel Archive}

Los Angeles is the site of a complex story of Jewish migration and urban diversity —one in which multiple Jewish diasporas meet, collide, merge, and maintain or lose their cultural distinctiveness while simultaneously weaving themselves into the larger fabric of Southern California. Sephardim add a distinctive but rarely acknowledged element to the region's Jewish, Middle Eastern, and Spanish-speaking population. Los Angeles has been portrayed as an Ashkenazi Jewish city (Vorspan and Gartner 1970; Wilson 2015), a (non-Jewish) Middle Eastern city (Waldinger and Bozorgmehr 1996), and a Mediterranean-style city (Starr 1973). In the first two examples, such descriptions relied on the city's twentieth-century demographic and economic realities, while the third vision was built on the romanticized aesthetic of climate, topography, and leisure in Southern California. These conceptions of the city have typically been explored independently of one another: Either as a story of a Jewish Boyle Heights (Sánchez 2004; Bernstein 2011) and Hollywood (Gabler 1989), or one of Iranian or Armenian ethnic enclaves (Kelley et al. 1993; Waldinger and Bozorgmehr 1996). Collecting, preserving, and describing local primary source materials, and making them accessible for research may help raise awareness of Sephardic history in Southern California in general, and Los Angeles in particular. These archival materials substantiate stories that are at once global and regional, diasporic and local, and link Southern California to North Africa, the Ottoman Empire, the eastern Mediterranean, and Europe.

Bob Hattem, past editor of El Shofar, the monthly newsletter of the STTI, is largely responsible for the STTI archive that exists today. He described the records he collected as an "invaluable link between the past and present, and the future. Every scrap of paper, every article, every bit of 'Temple Family News,' every Rabbi's message, every Cantor's Corner, every 'Orchids 'n' Onions,' yes, even every Joeha ${ }^{1}$ story is kept on file. Nothing is discarded. This is the basis for our Sephardic history and future" (Hattem 1983, 10).

Born in Los Angeles in 1919, Maurice I. "Bob" Hattem (Figure 2) was raised in the city's small Sephardic community, founded by Judeo-Spanish speaking immigrants from the Ottoman Empire and the broader Mediterranean basin. His Istanbul-born father was a lay leader in the city's

1 "Joeha," more commonly spelled as Joha, epitomizes the fool in Sephardic, Levantine, and Middle Eastern folk culture. 
Sephardic community since its founding in the 1910s and a major retail grocer in Los Angeles who developed the modern supermarket (Hattem 1979). The younger Hattem was educated at UCLA and Syracuse University and served in the Signal Corps during World War II. Throughout his life he served as a board member for historical societies such as the Native Sons of the Golden West and the Los Angeles City Historical Society, and on the newsletter editorial boards of the Department of California Jewish War Veterans, the American Jewish Friends of Turkey, and the Society for Crypto-Judaic Studies (HaLapid).

When he became the editor of El Shofar in 1980, Hattem embarked on a quest to create a temple archive that chronicled all aspects of its history. Many of the materials he collected were used to prepare articles for El Shofar and the academic journal Western States Jewish History Quarterly. Upon his retirement from El Shofar in July 1986, Hattem decided to serve as the dedicated temple archivist. But the creation of the temple archives was not a solo endeavor. Hattem formed a committee consisting of the temple's executive secretary, Sue Halfon, and four others, to collect, label, and organize the materials by his self-made numbering and filing system complete with an index-card catalog for cross-referencing subjects and individuals. By the following year, the team had completed an inventory and catalog of the collection and had begun the conservation process, placing items in protective sleeves and archival boxes.

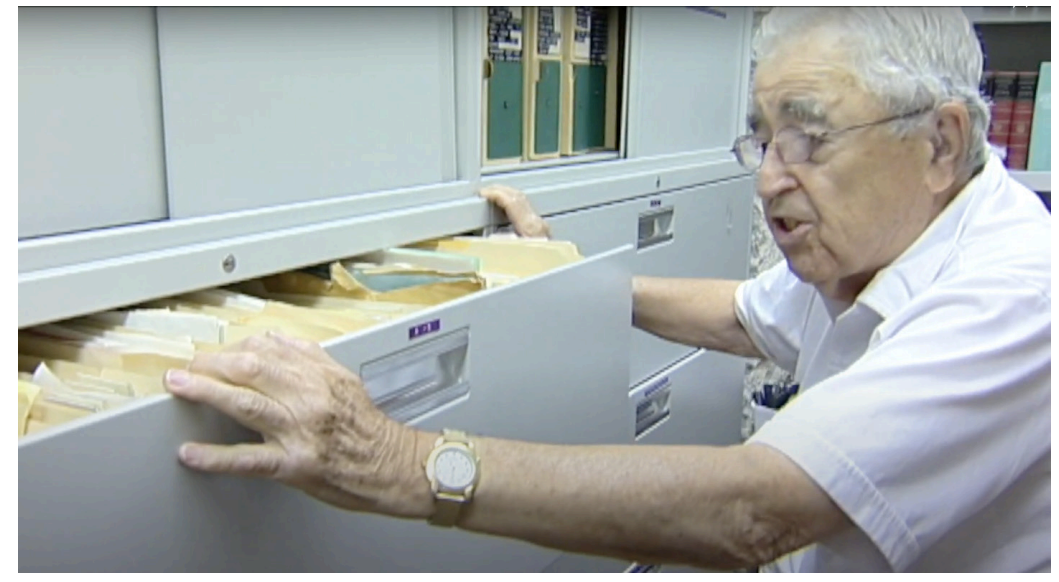

Figure 2. Maurice I. "Bob" Hattem (1919-2014) at the STTI archive. A screenshot from the STTI Centennial Video, https://www.youtube. $\underline{\mathrm{com} / \text { watch? } \mathrm{v}=\mathrm{rOER} \times \mathrm{Zpw} V \mathrm{bs} \& \text { feature }=\mathrm{emb} \text { title }}$

Throughout the late 1980s and 1990s, the team continued gathering materials from the temple and also began accepting documents, photos, and ephemera from congregants, who were eager to secure a safe place for their belongings. The donations included Ladino-language newspapers published in Manhattan, mid-century bar mitzvah photos, prayer books, family letters, and Ottoman birth certificates. These new acquisitions were stored in a small office tucked behind one of the temple's classrooms. A consummate collector, Hattem led the archives through the days of word processors, personal computers, and the early internet, and eventually invested in archival software and began to digitize certain materials. Hattem died on April 4, 2014, at the age of 95, yet his passion, and commitment to Sephardic archives continue to live on through the STTI records. 
The history of STTI, and of Sephardic Jewry in Southern California, begins with the early twentieth century migration of Jews from around the Mediterranean and the Middle East to Los Angeles (Kramer 1996 and Stern 1980). While most of them arrived from the Ladino-speaking area of Ottoman Anatolia, others came from Bulgaria, Romania, Palestine, Algeria, and Egypt. Many had traveled through New York City and Seattle, important nodes on the map of American Sephardic life. Sephardic Jews in Los Angeles established communal institutions almost immediately. In the first decade after their arrival, several small organizations of Sephardic Jews formed and fractured, due to the similarities and differences between the Rhodeslis (those originating in Rhodes) and the Turkinos (those originating in Anatolia). In 1920, a few dozen Levantine and Mediterranean immigrant men living and working in downtown Los Angeles founded the Comunidad Sefardi de Los Angeles (The Sephardic Community of Los Angeles), the first iteration of STTI. One notable item in the STTI collection marking these early years is a Hebrew document from 1912 authored by the chief Sephardic rabbi of Jerusalem recognizing the Bursa-born Abraham Caraco as the gabai (administrative leader) of the Los Angeles community (Figure 3). STTI broke ground at its current location on Wilshire Boulevard in Los Angeles's Westwood neighborhood in 1970, after more than three decades in South LA. It formally relocated there in 1975 and dedicated its sanctuary in 1981.

The STTI archive contains organizational records, meeting minutes, newsletters, pamphlets, and flyers, written primarily in Ladino and English. The collection also includes scrapbooks and newspaper clippings, some compiled by Bob Hattem's archive team and others donated by individuals, and an impressive number of reel-to-reel audiotapes, audiocassettes, and VHS tapes with a heavy focus on Sephardic music. Especially noteworthy are the recordings, transcriptions, and notes of Turkish-born musicians and of amateur ethnomusicologists Emily and Isaac Sene.

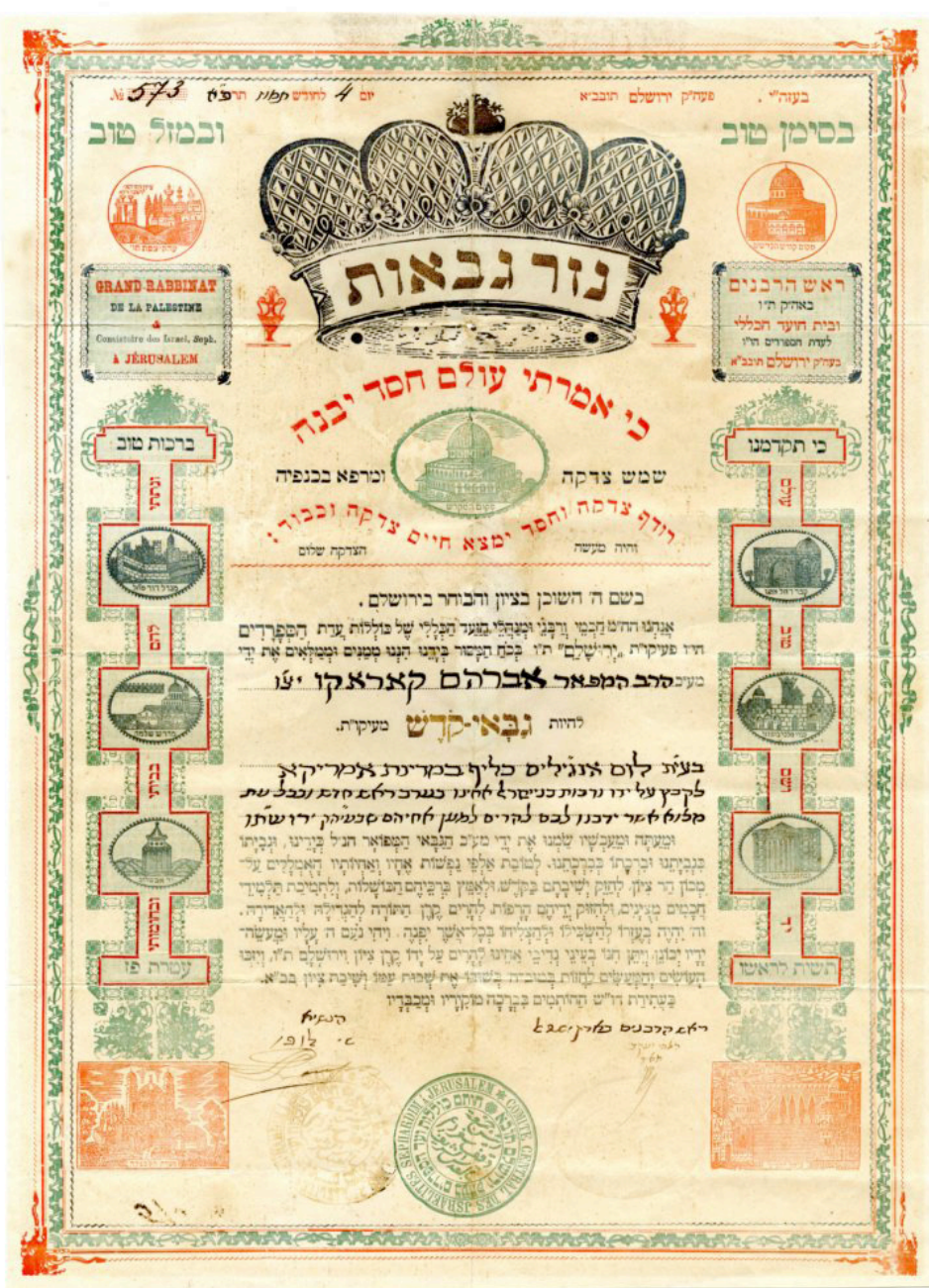

Figure 3. Rabbinical document, gifted by Caraco's granddaughter, Julie Passy Breitstein, 1912. Sephardic Temple Tifereth Israel records (Collection 2340), UCLA Library Special Collections 


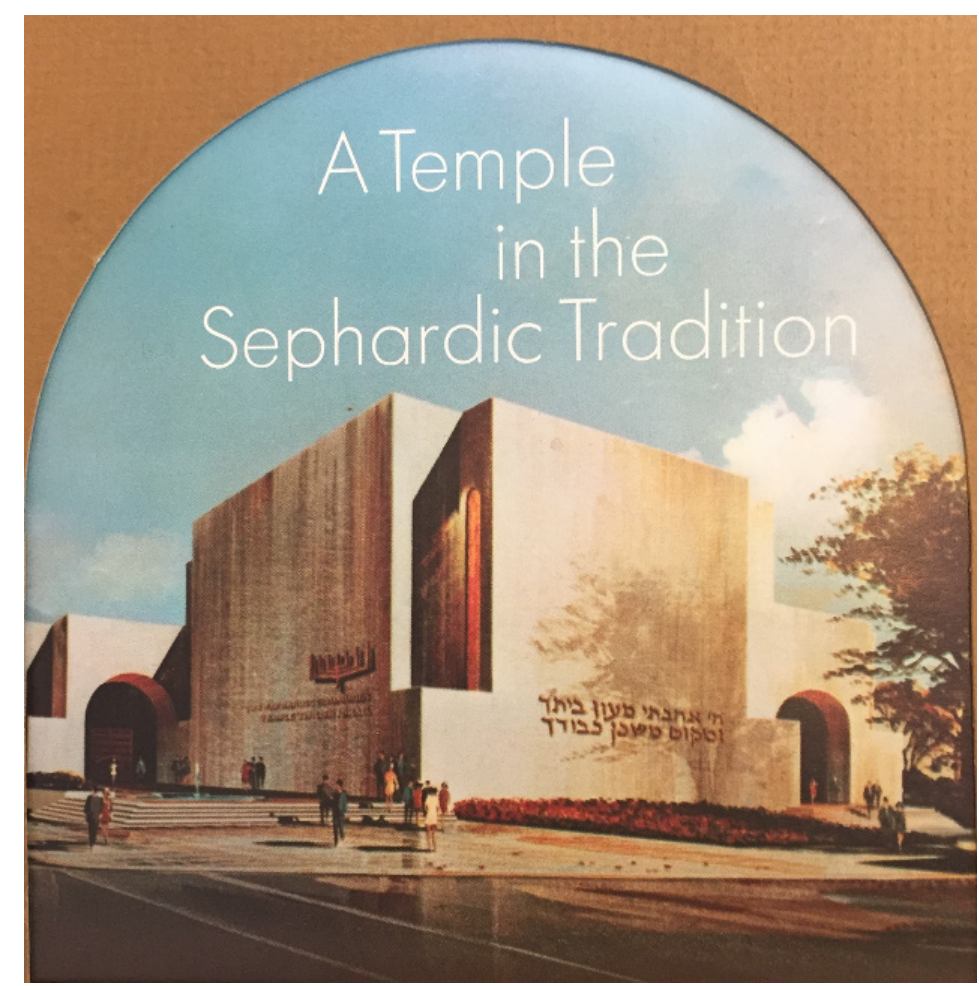

Figure 4. A 1971 prospectus for the Sephardic Temple Tifereth Israel on 10500 Wilshire Boulevard, Los Angeles. Sephardic Temple Tifereth Israel records (Collection 2340), UCLA Library Special Collections

Showcasing Sephardic culture and history was evidently a prominent activity of the STTI community. Even before the start of the formal archives, Rabbi Jacob Ott (1919-2005) emphasized the importance of collecting and writing the history of Sephardim in Los Angeles, and he gave lectures around the country on Sephardic history (Blecker 1987). STTI members were also involved in performing, writing, speaking, and teaching on Sephardic subjects in local, national, and international venues (Alcana 1957-1997). Bulgaria-born Leon Ligier (1879-1977) completed a manuscript surveying Sephardic history (Ligier 1975 [1972]), and the Sisterhood produced the 1971 cookbook, Cooking the Sephardic Way, which introduced American audiences to Sephardic cuisine.

While the bulk of the archive was gathered in the mid-1980s through the mid-1990s, Hattem's collecting efforts and involvement in the archive lasted nearly until the end of his life. Newsletters, event programs, and VHS tapes of community events like its "Ethnic Nights," showcasing the Persian, Greek, Moroccan, or Cuban cultures of STTI's congregants, make up the most recent additions to the archive and reflect the evolution of the community over the past two decades, particularly the increasing involvement of Persian Jews. From the mid-1990s to the 2015 UCLA's acquisition, the STTI archive continued collecting congregation papers and programs, but few community materials found their way into the archive. 
The engagement of UCLA with the STTI community, beyond individual members of STTI having attended the university for undergraduate or advanced degrees, is reflected in the scholarly work of students and scholars who have chosen the Sephardic community as a subject of study. Ties between UCLA and the STTI community go back at least as far as the 1950s when UCLA scholars Joseph Silverman and Samuel Armistead conducted their fieldwork on Ladino balladry. The relationships have grown over the decades to the extent that the Maurice Amado Foundation, a local family philanthropy that promotes the knowledge of Sephardic Jewish culture and heritage, endowed a position in Sephardic studies at UCLA in the early 1990s. Several current advisory board members of UCLA's Leve Center for Jewish Studies come from the local Sephardic community, including the STTI.

With those connections in place, and spurred by the 2014 passing of the archive's steward Bob Hattem, STTI librarian Annette Goldsmith proposed that the STTI archives be moved to UCLA.

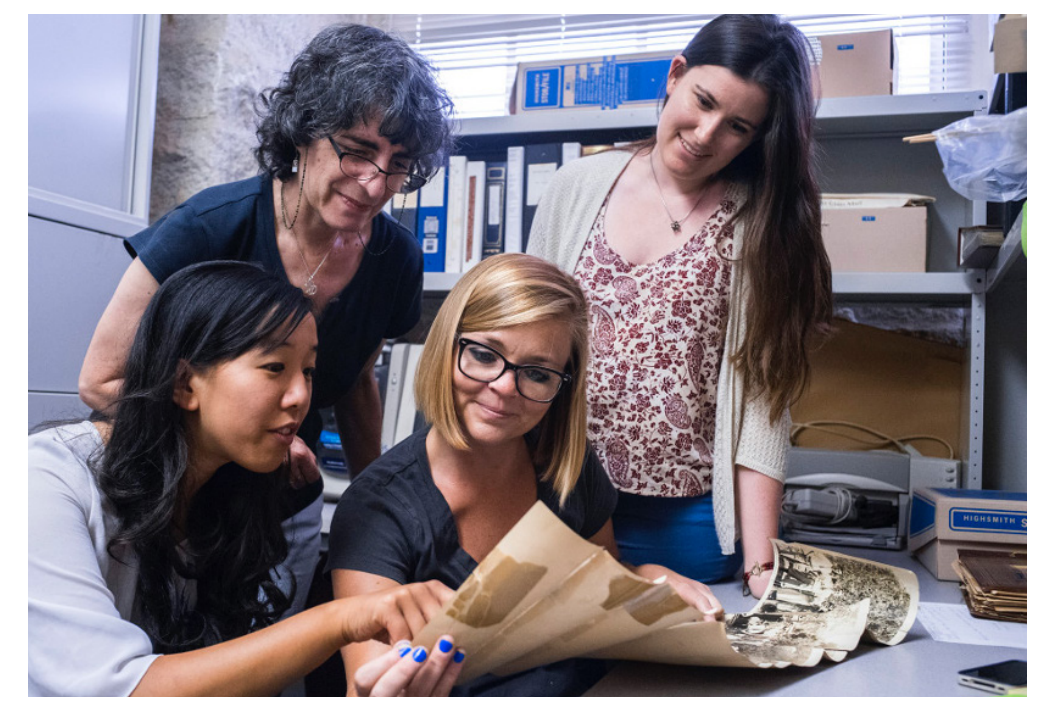

Figure 5. In the original archive room at STTI. From left: intern Joanna Chen Cham, temple librarian Annette Goldsmith, Caroline Luce, and intern Devora Lewis
In 2015 the archival materials made their way to their new home, a mere mile and half away. Two years later, processing began with the support of UCLA Library Special Collections' Center for Primary Research and Training, which hires and trains graduate students in archival methods for arranging, preserving, and describing primary source materials. In May 2019, the finding aid for the STTI records was published on the Online Archive of California website, at https://oac.cdlib.org/findaid/ ark:/13030/c8xw4rjn.

From the perspective of UCLA, its library, and its special collections department, the acquisition fell neatly within their shared mission as a public university to advance relationships between the academy and the local community, and in particularly, to prioritize collections that reflect local, Southern California and Los Angeles-area communities. These archives serve the research needs of faculty, students, and visiting researchers and help to bolster the position of UCLA as a center of Sephardic studies nationwide. 


\section{uCla Sephardic Archive Initiative: Online and In-Person}

The SAI recently launched its online portal at sephardiclosangeles.org, with the help of a CJS team. ${ }^{2}$ Its first major digital publication, "Sarajevo to City of Angels: The Remarkable Story of $\mathrm{Al}$ and Rose Finci," incorporates archival, historical, and digital resources. The SAI relies heavily on its relationships with the local Sephardic community. An online exhibition, "100 Years of Sephardic Los Angeles," features brief essays that explore the historical and cultural legacies of Sephardic Los Angeles, often using information gleaned from its archival holdings. Contributors include scholars, faculty, undergraduate and graduate students, as well as community members. The essays span the history of Sephardic life in Southern California, from the days of the Spanish and Mexican El Pueblo de Nuestra Señora la Reina de los Ángeles to twenty-first century Tehrangeles, and cover immigrant bootblacks, Ladino language, music and performance, youth culture, architecture, and Sephardic Jews' involvement in the "oriental goods" business. The exhibition went live on February 9, 2020, to coincide with the centennials of UCLA and the establishment of the Sephardic community in Los Angeles, ${ }^{3}$ as well as the twenty-fifth anniversary of the Center for Jewish Studies at UCLA.

The SAI has sought to discover relevant materials held by individuals in the Los Angeles area. It was this objective that led the SAI and its partners

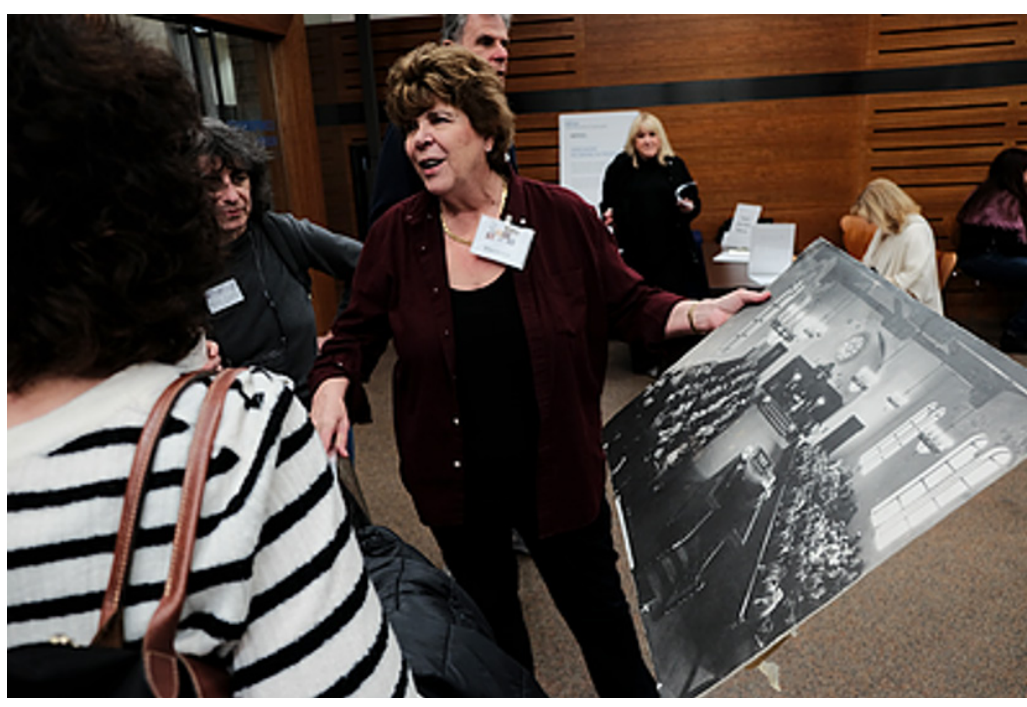

Figure 6. Marcia Israel Weingarten holds a 1930s reproduction of Temple Tifereth Israel's interior. "Sephardic Antique Roadshow," March 11, 2018, UCLA's Charles E. Young Library. Photo: David Wura at UCLA Library to organize

"Save the Data: A Sephardic Antique Roadshow" in March 2018 (Figure 6). The event was hosted by UCLA's Charles E. Young Research Library. An invited group of academic, student, and community volunteers were on hand to help attendees identify and translate the documents they brought in. Librarians and archivists also advised attendees on the preservation of their family treasures and on best practices and standards for digitizing documents.

People came to the open house with photos, letters, and prayer books, among other memorabilia. Many documents were in Ladino, including a decade's worth of meeting minutes from the

\footnotetext{
${ }^{2}$ The CJS team included Digital Content Designer David Wu and Research and Digital Projects Manager Dr. Caroline Luce. Wu and Dr. Luce previously collaborated on CJS's multifaceted Mapping Jewish LA project, at http:// www.mappingjewishla.org.
}

${ }^{3}$ See also the "STTI Centennial Video," at https://www.youtube.com/watch?v=rOERxZpwVbs\&feature=emb title. 
Peace and Progress Ladies' Auxiliary (1930s-1940s); others were in French, Hebrew, Arabic, Greek, and Italian. Aside from the immediate goal of encountering "new" materials, the event furthered SAI's relationships with attendees. Stories of family journeys from Morocco, Greece, and Rhodes enhanced SAI volunteers' knowledge of North African intellectual life, Ottoman Jewish society, and American immigration patterns.

\section{FINAL WORDS}

The growth and advancement of Sephardic studies depend on projects like the Sephardic Archives Initiative, which fosters the interconnectedness that is so characteristic of Sephardic history in Los Angeles. Sephardic Jews bring different perspectives to Jewish, American, immigrant, ethnic, and cultural histories that, like the array of expertise needed to shepherd an archive, speak to the necessity of collaboration. The librarians and archivists at UCLA are key to the SAI's ability to reach its goals. The SAI's collecting efforts also engage local individuals, families, and communities and its digital projects help contextualize and showcase Sephardic history.

In that sense, the interdisciplinary approach that is so central to Sephardic studies mirrors the same diversity of the SAI staff. The community archive flourishes in the hands of a community of archivists.

\section{SOURCES}

Angel, Marc D. 1982. La America: The Sephardic Experience in the United States. Philadelphia: Jewish Publication Society of America.

Baron, Salo. 1950. "American Jewish History: Problems and Methods." Publications of the American Jewish Historical Society 39 (3): 207-266.

Ben-Ur, Aviva. 2001. "In Search of the American Ladino Press: A Bibliographical Survey, 19101948." Studies in Bibliography and Booklore 21: 10-52. . 2009. Sephardic Jews in America: A Diasporic History. New York: New York University Press.

Bernstein, Shana. 2011. Bridges of Reform: Interracial Civil Rights Activism in Twentieth-Century Los Angeles. Oxford: Oxford University Press.

Blecker, Rhoda. 1987 "Rabbinic Interview: Rabbi Jacob Ott.” The Jewish Calendar 5 (1): 3.

Gabler, Neal. 1989. An Empire of Their Own: How the Jews Invented Hollywood. New York: Anchor Books. 
Hattem, Maurice I.(“Bob”). 1983. "Editor's Column,” El Shofar: Bulletin of Sephardic Temple Tifereth Israel 5 (1), September: 10. . 1979. "I. M Hattem and His Los Angeles Supermarket.” Western States Jewish History Quarterly 11 (3): 243-251.

Kelley, Ron, Jonathan Friedlander, and Anita Colby, eds. 1993. Irangeles: Iranians in Los Angeles. Berkeley: University of California Press.

Kramer, William M., ed. 1996. Sephardic Jews in the West Coast States: The Los Angeles Sephardic Experience, special issue of Western States Jewish History 28 (4).

Papo, Joseph M. 1987. Sephardim in Twentieth Century America: In Search of Unity. San Jose, CA: Pele Yoetz Books.

Sánchez, George J. 2004. “' 'What's Good for Boyle Heights Is Good for the Jews': Creating Multiracialism on the Eastside during the 1950s." American Quarterly 56 (3): 633-661.

Sephardic Sisterhood of Temple Tifereth Israel. 1971. Cooking the Sephardic Way. Los Angeles: Sephardic Temple Tifereth Israel.

Starr, Kevin. 1973. Americans and the California Dream, 1850-1915. New York: Oxford University Press.

Stern, Stephen. 1980. The Sephardic Jewish Community of Los Angeles. New York: Arno Press.

Sutton, Joseph A. D. 1979. Magic Carpet: Aleppo-in-Flatbush: The Story of a Unique Ethnic Jewish Community. New York: Thayer-Jacoby.

Vorspan, Max, and Lloyd P. Gartner. 1970. History of the Jews of Los Angeles. San Marino, California: The Huntington Library.

Waldinger, Roger, and Mehdi Bozorgmehr, eds. 1996. Ethnic Los Angeles. New York: Russell Sage Foundation.

Wild, Mark. 2008. Street Meeting: Multiethnic Neighborhoods in Early Twentieth-Century Los Angeles. Berkeley: University of California Press.

Wilson, Karen, ed. 2013. Jews in the Los Angeles Mosaic. Berkeley: University of California Press. 
Sephardic Temple Tifereth Israel records (Collection 2340). UCLA Library Special Collections, Charles E. Young Research library. University of California, Los Angeles.

Alcana, Yolande. 1957-1997. "Sephardic Mini-Musical.” A program. Box 47, Folder 4; "Sephardic Shabbat.” A program. Box 47, Folder 5.

Ligier, Leon. 1975 [1972]. "The Odyssey of the Jews of Spain and Portugal: Sephardim in Transition." A manuscript (two versions). Box 37, Folders 5-6; Box 38, Folders 1-2. 